\title{
NOTE
}

\section{THE RELATIONSHIP BETWEEN VALVE DIAMETER AND NUMBER OF CENTRAL FULTOPORTULAE IN THALASSIOSIRA WEISSFLOGII (BACILLARIOPHYCEAE) $^{1}$}

\author{
Jeffrey R. Johansen ${ }^{2}$ \\ Solar Energy Research Institute, 1617 Cole Boulevard, Golden, Colorado 80401 \\ and \\ Edward Theriot \\ Great Lakes Research Division, University of Michigan, Ann Arbor, Michigan 48109
}

\begin{abstract}
Cells well below the reported minimum size for Thalassiosira weissflogii (Grunow) Fryxell et Hasle were observed in two unialgal cultures. The relationship between diameter and number of central fultoportulae was found to be very regular. Regression analysis of three different populations showed equivalent slopes and $\mathrm{r}^{2}$ values above $80 \%$. The y-intercepts were significantly different and support observations in the literature that nonmarine values of $\mathrm{T}$. weissflogii have fewer central fultoportulae than marine forms.
\end{abstract}

Key indexwords: diatoms; fultoportulae; morphometrics; strutted processes; Thalassiosira

The morphology of Thalassiosira weissflogii (Grunow) Fryxell et Hasle ( $=T$. fluviatilis Hustedt) has been thoroughly discussed by Hasle (1961) and Fryxell and Hasle (1977). The species has been characterized as a mesohalobic Thalassiosira having a marginal ring of fultoportulae (9-16 in $10 \mu \mathrm{m})$, an irregular central ring of 7-18 (2-28) fultoportulae, a single rimoportula, very fine areolae, and a valve diameter of $12-32 \mu \mathrm{m}$. Hasle (1961) noted an apparent relationship between valve diameter and number of fultoportulae in the central ring. This relationship has not been reported for any other Thalassiosira species.

Kiss et al. (1984) noted that nonmarine valves of T. weissflogii seem to have fewer central fultoportulae than do marine forms. Thus there may be at least two different components (specimen size and environment of development) underlying variation in central fultoportulae count. In our study of the morphology of two strains of $T$. weissflogii we have observed cells that extend the range of valve diameter previously recorded. We have also quantified the relationship between diameter and number of fultoportulae in the central ring. This paper confirms the opinions of both Hasle and Kiss et al. and dem-

\footnotetext{
${ }^{1}$ Accepted: 15 June 1987.

${ }^{2}$ Address for reprint requests.
}

onstrates that at least part of the diameter component of variation in natural populations can be explained by vegetative size reduction within clones.

Two unialgal cultures of $T$. weissflogii were used for this study, THALA2 and THALA5 (SERI Microalgae Culture Collection). THALA2 was originally collected by Bill Barclay in November, 1984, from a warm spring on the Colorado River near Glenwood Springs, Colorado. THALA5 was originally collected by Richard York in December, 1985, from Pond 4 of the Mariculture Research and Training Center on Oahu, Hawaiian Islands. THALA2 and THALA5 were grown in SERI Type I/55 medium (Barclay et al. 1986) and f/2 (McLachlan 1973), respectively, at $15^{\circ} \mathrm{C}$ on a 18:6 h LD cycle. Cells of THALA2 were rinsed, air-dried on cover slips fixed to aluminum stubs, coated with gold-palladium, and observed in the scanning electron microscope at accelerating voltages of $10-15 \mathrm{kV}$. Healthy cells (early stationary phase) of both cultures were acid cleaned, rinsed, and mounted in Naphrax resin. Valve diameter and number of fultoportulae on the valve face were recorded for over 50 valves from each culture. Methods of regression and of comparing regression equations are given in $\mathrm{Zar}$ (1984).

Scanning electron micrographs (Fig. 1) confirmed that cultures belonged to Thalassiosira weissflogii. Cells of THALA2 ranged from $7-23.5 \mu \mathrm{m}$ in diameter. Those of THALA5 ranged from 3.8-15 $\mu \mathrm{m}$ in diameter. Thus in both strains cells smaller than the published minimum diameter of $12 \mu \mathrm{m}$ were observed, extending the diameter range of this species to 3.8-32 $\mu \mathrm{m}$. In the original description of Micropodiscus weissflogii Grunow (in Van Heurck 1885), valve diameter was recorded as 5-15 $\mu \mathrm{m}$. However, in their re-examination of type material in the Van Heurck collection, Fryxell and Hasle (1977) recorded cells ranging $15-21 \mu \mathrm{m}$ in diameter, indicating Grunow's measurements were probably in error. Other dimensions, such as proximity of marginal fultoportulae $(10-13$ in $10 \mu \mathrm{m})$ and total number of central fultoportulae (2-15), were within the ranges described previously (Fryxell and Hasle 1977).

Light micrographs clearly demonstrate the relationship between diameter and number of central fultoportulae (Figs. 2-10). For both strains, a simple regression revealed a striking relationship between these two characters (Fig. 11). In both cases, $r^{2}$ was 

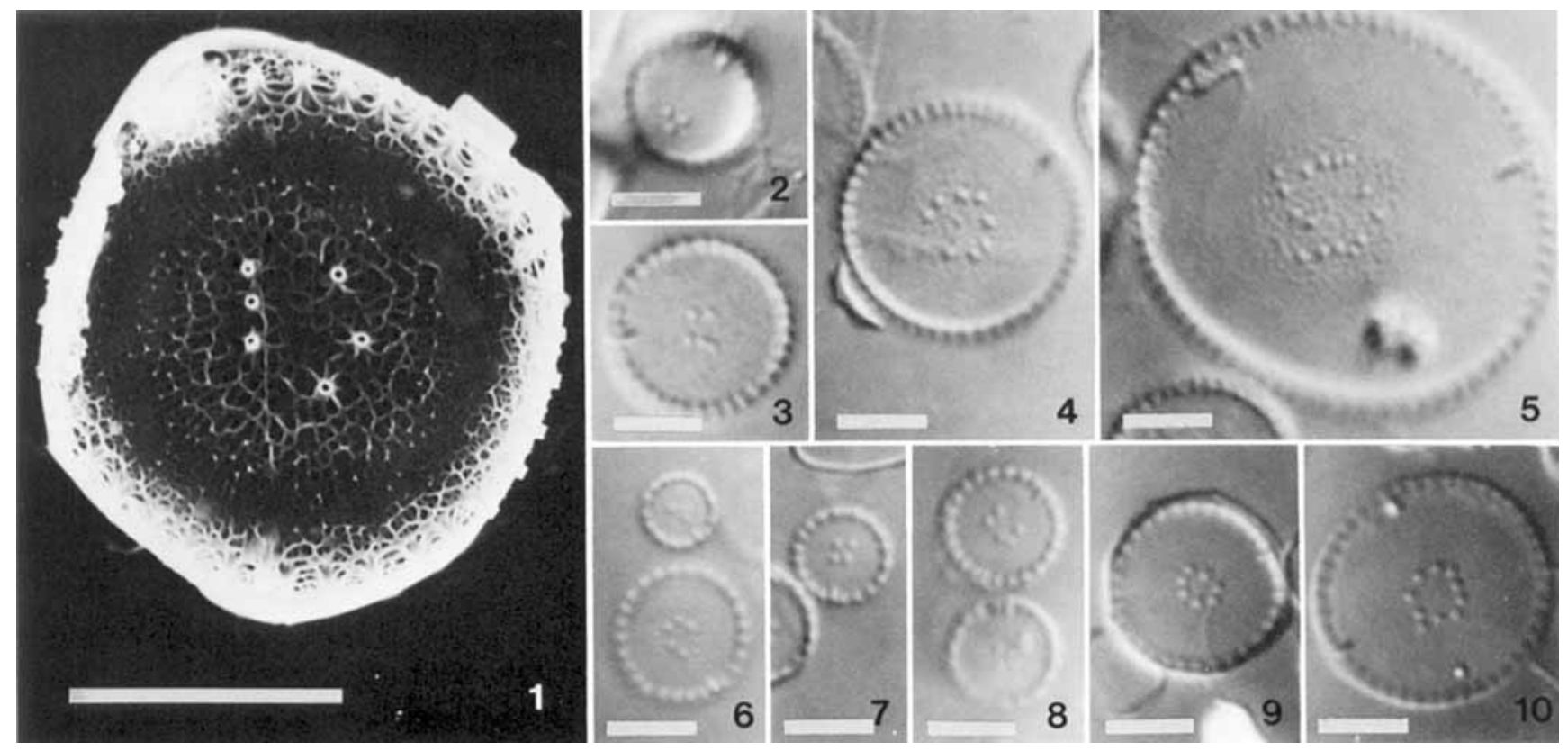

Figs. 1-10. Valvar views of Thalassiosira weissflogii. Fig. 1. Scanning Electron Micrograph of cell from THALA2. Figs. 2-5. Size series of THALA2. Figs. $6-10$. Size series of THALA5. Scale bars $=5 \mu \mathrm{m}$.

above $85 \%$. The slopes of the two regressions $(0.74$ in THALA2 and 0.73 in THALA5) were not significantly different, but the y-intercept values $(-2.27$ in THALA2 and -0.23 in THALA5) were. Though this difference was not large enough to merit any taxonomic separation, it does indicate that this character can be used to separate populations. When the 9 pairs of data from Hasle (1961) were regressed, the regression equation was $\mathrm{y}=0.69 \mathrm{x}-1.33$, with $r^{2}=81 \%$. The slope of this equation was not significantly different from that of either of our strains. Considering the small sample size and consequent small standard error $(\mathrm{s} / \sqrt{\mathrm{n}})$, this is remarkably consistent with our data.

THALA5 probably represents a marine strain, having been collected in mariculture ponds on the island of Oahu which has no natural lakes and few permanent streams. THALA2 was isolated from an inland locality of $12 \mathrm{mmho} \cdot \mathrm{cm}^{-1}$ conductivity. To the extent that these clones are representative of those of marine and nonmarine habitats, the differences in $y$-intercept values between THALA5 and THALA2 suggest that nonmarine specimens of $T$. weissflogii tend to have fewer central fultoportulae than do marine specimens at a given diameter. Kiss et al. (1984) did not recognize the effect of diameter, but otherwise suggested the same hypothesis based on published data on assemblages of $T$. weissflogii from Europe, North America, and South Africa (Hasle 1961, Lowe and Busch 1975, Belcher and Swale 1977, Fryxell and Hasle 1977, Schoeman and Archibald 1977, Makarova et al. 1979).

At least part of the relationship between diameter and fultoportulae count in nature is apparently at- tributable to size differences among individuals since such a relationship was observed in our cultures. How much is due to differences between genetically different clones of different sizes is uncertain. Our data suggest that there is little inherent stochastic "noise" in fultoportulae number within a clone under constant conditions. Thus, it seems probable that the majority of size-free variation in fultoportulae count in nature represents differences in genotype and/or environment of development.

Central fultoportulae count is a highly variable character in many centric diatoms. Among members of the Thalassiosiraceae, a statistical relationship between central fultoportulae count and diameter has been established for $T$. tumida (Janisch) Hasle and five species of Stephanodiscus Ehrenb. (Genkal and Kuzmin 1979, Theriot and Stoermer 1984a, b, c, Wood et al. 1987). In $S$. niagarae Ehrenb. and $T$.

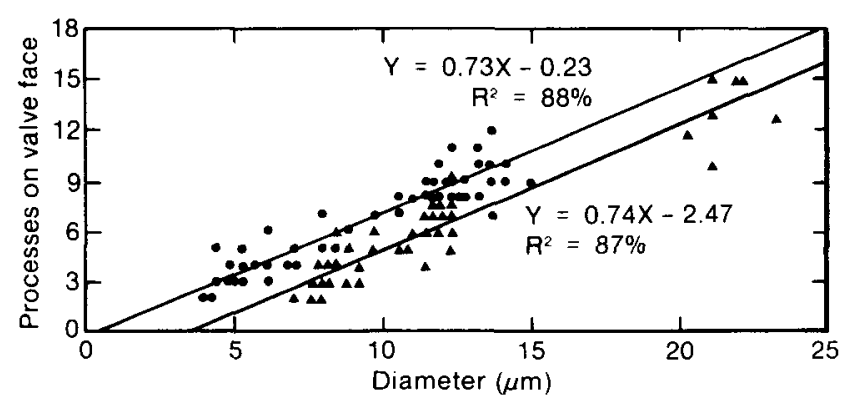

Fig. 11. Regression lines and equations for the relationship of central fultoportulae to diameter. Upper equation and line (data points circles) is THALA5. Lower equation and line (data points triangles) is THALA2. 
tumida, variation in central fultoportulae count also has a partial statistical dependence on environmental parameters (Secchi transparency and ambient Si: $P$ ratios in the former species, and light intensity in the latter). Thus, the situation in T. weissflogii of central fultoportulae count having several independent sources of variation is not unique.

As morphometric studies are pursued on centric diatoms, more such examples are likely to be encountered. Intrinsic (e.g. size) and extrinsic (e.g. nutrient concentrations) phenomena are independent factors that can cause morphological variation in diatoms. The power of morphometric analysis is indicated by the fact that the few such studies performed on centric diatoms have routinely uncovered and identified these independent factors both in field (Genkal and Kuzmin 1979, Theriot and Stoermer 1984a, b, c, 1986) and in laboratory studies (Wood et al. 1987, this study).

The relationship between diameter and number of central fultoportulae is shown here to be very consistent in three widely separated populations of the same species. Hasle's material was collected in the cold temperate waters of the inner Oslofjord, THALA2 from an inland warm spring in a temperate climate, and THALA 5 from a shallow brackish pond in the tropics. The consistency of this relationship suggests that in future studies of other Thalassiosira species, the relationship between diameter and number of central fultoportulae should be documented.

This work was supported by the Biomass Energy and Waste'Technology Division of the U.S. Department of Energy under WPA 513, contract number DE-ACO2-83CH10093. Ed Theriot was supported by NSF grant BSR 8507709.

Barclay, W., Johansen, J., Chelf, P., Nagle, N., Roessler, P. \& Lemke, P. 1986. Microalgae Culture Collection. Solar Energy Research Institute, Golden, Colorado, $149 \mathrm{pp}$.

Belcher, J. H. \& Swale, E. M. F. 1977. Species of Thalassiosira (diatoms, Bacillariophyceae) in the plankton of English rivers. Br. Phycol. J. 12:291-7.
Fryxell, G. A. \& Hasle, G. R. 1977. The genus Thalassiosira: some species with a modified ring of central strutted processes. Nor'a Heduigia, Beih. 54:67-98.

Genkal, S. I. \& Kuzmin, G. V. 1979. Biometric analysis of main structural elements of valves in the species of the genus Stephanodiscus Ehr. (Bacillariophyta). Bot. Zhurnal 64:1237-44. (In Russian).

Hasle G. R. 1961. The morphology of Thalassiosira fuviatilis from the polluted inner Oslofjord. Nytt Mag. Bot. 9:151-6.

Kiss, K. T., Kovacs, K. \& Dobler, E. 1984. The fine structure of some Thalassiosira species (Bacillariophyceae) in the Danube and the Tisza rivers. Arch. Hydrobiol. Suppl. (Algological Studies) $67: 409-15$

Lowe, R. L. \& Busch, D. E. 1975. Morphological observations on two species of the diatom genus Thalassiosira from freshwater habitats in Ohio. Trans. Am. Microsc. Soc. 94:118-23.

Makarova, I. V., Genkal, I. I. \& Kuzmin, G. V. 1979. Species of the genus Thalassiosira Cl. (Bacillariophyta), found in continental water-bodies of the U.S.S.R. Bot. Zhurnal 64:513-33. (In Russian).

McLachlan, J. 1973. Growth media-marine. In Stein, J. R. [Ed.] Handbook of Phycological Methods, Culture Methods and Growth Measurements. Cambridge University Press, New York, pp. $25-51$.

Schoeman, F. R. \& Archibald, R. E. M. 1977. Thalassiosira fui'atilis Hustedt. The Diatom Flora of Southern Africa No. 2. C.SIR Special Report WAT 50:1-9.

Theriot, E. \& Stoermer, E. F. 1984a. Principal component analysis of Stephanodiscus: observations on two new species from the Stephanodiscus niagarae complex. Bacillaria 7:37-58.

1984b. Principal component analysis of character variation in Stephanodiscus niagarae Ehrenb.: morphological variation related to lake trophic status. In Mann, D. G. [Ed.] Proceedings of the Serenth International Diatom Symposium. Otto Koeltz, Koenigstein, pp. 97-111.

- 1984c. Principal component analysis of variation in Stephanodiscus rotula and S. niagarae (Bacillariophyceae). Syst. Bot. 9:53-9

- 1986. Morphological and ecological evidence for two varieties of Stephanodiscus niagarae. In Ricard, M. [Ed.] Proceedings of the Eighth International Diatom Symposium. Otto Koeltz, Koenigstein, pp. 385-94.

Van Heurck, H. 1885. Synopsis des Diatomees de Belgique. Brouwers \& Co., Antwerp, Belgium, 235 pp.

Wood, A. M., Lande, R. \& Fryxell, G. A. 1987. Quantitative genetic analysis of morphological variation in an antarctic diatom grown at two light intensities. J. Phycol. 23:42-54.

Zar, J. H. 1984. Biostatistical Analysis, 2nd ed. Prentice Hall, Inc. Englewood Cliffs, New Jersey, 718 pp. 